\title{
Dual reporter genes enabling cell tracing with viable and reliable selection of various cell types
}

\author{
C. N. Hwang $\cdot$ S. Hong $\cdot$ S. S. Choi $\cdot$ K. S. Lee $\cdot$ \\ S. S. Park - S. H. Lee
}

Published online: 21 September 2006

(C) Springer Science+Business Media B.V. 2006

\section{Erratum to: Biotechnol Lett (2006) 28: 287-293 DOI 10.1007/s10529-005-5715-9}

No Acknowledgements section was included in the original. It is printed below.

Acknowledgements This research has been supported by the Intelligent Microsystem Center which carries out one of the 21st century's Frontier R\&D Projects sponsored by the Korea Ministry of Commerce, Industry and Energy. This work was also partially supported by the Research Center for Transgenic Cloned Pig, Choongnam National University, sponsored by the Korea Science and Technology Foundation.

The online version of the original article can be found at http://dx.doi.org/10.1007/s10529-005-5715-9

C. N. Hwang $\cdot$ S. Hong $\cdot$ S. S. Choi $\cdot$ K. S. Lee

S. S. Park $\cdot$ S. H. Lee $(\square)$

School of Life Sciences and Biotechnology, Korea

University, Seoul 136-701, Republic of Korea

e-mail: sangho@korea.ac.kr 